\title{
Follow the light — diurnal and seasonal variations in vertical distribution of the mesopelagic fish Maurolicus muelleri
}

\author{
Arved Staby*, Dag L. Aksnes \\ University of Bergen, Department of Biology, PO Box 7803, 5020 Bergen, Norway
}

\begin{abstract}
Previous 1 d studies (Giske et al. 1990, Sarsia 75:65-81; Baliño \& Aksnes 1993, Mar Ecol Prog Ser 102:35-50; Rasmussen \& Giske 1994, Mar Biol 120:649-664) of the mesopelagic fish Maurolicus muelleri have suggested that their vertical distribution changes as though they were following a constant light intensity, sometimes termed the 'isolume'. Here we investigated whether such behaviour is consistent under varying light conditions and over an extended period. We analysed acoustic observations of ontogenetically varying scattering layers (SLs) versus surface irradiance from selected days during a 9 mo period (January to September 2008). On the majority of days, a strong correlation $\left(r^{2}>0.90\right)$ between upper SL depth and surface irradiance was observed. The SLs of $M$. muelleri suggest that this species has a restricted range of preferred light intensities. This tendency was found regardless of season and migration phase, i.e. during dawn descent, dusk ascent and daytime. The irradiance estimated at the top of the upper SL for consecutive days, regardless of migration phase, varied on average by less than 1 order of magnitude, while the average monthly estimates for the descent, ascent and daytime periods varied from 0.004 to $0.39 \mu \mathrm{E} \mathrm{m}^{-2} \mathrm{~s}^{-1}, 0.08$ to $2.35 \mu \mathrm{E} \mathrm{m}{ }^{-2}$ $\mathrm{s}^{-1}$ and 0.02 to $0.68 \mu \mathrm{E} \mathrm{m}^{-2} \mathrm{~s}^{-1}$, respectively. During their ascent, fish experienced up to 9 times higher light intensities than during the descent. Our study suggests that the vertical migration of $M$. muelleri emerges because of a vertical habitat selection that can be characterised by the preference of a restricted range of light intensities and that these intensities may be state and age dependent.
\end{abstract}

KEY WORDS: Diel vertical migration - Preferred light range · Isolume · Scattering layers • Maurolicus muelleri • Ontogeny · Hydroacoustics

\section{INTRODUCTION}

Light is an environmental variable that together with abiotic, e.g. temperature or oxygen, and biotic, e.g. food abundance or predator density, factors determines which habitat marine organisms occupy in the pelagic environment (McFarland 1986, de Robertis 2002, Metcalfe et al. 2008, Boscarino et al. 2009). Visually foraging fish require light to sustain feeding (Eggers 1978, Aksnes \& Utne 1997, Ryer \& Olla 1999, Boscarino et al. 2010), but the anti-predator behaviour of many fish also appears to be affected by light (Kaartvedt et al. 1998, Ryer \& Olla 1998). Changes in the vertical distribution of fish have thus been associated with concurrent changes in surface irradiance
(Roe 1983, Baliño \& Aksnes 1993, Rasmussen \& Giske 1994, Kaartvedt et al. 1996, Frank \& Widder 2002).

The pelagic environment offers few possibilities for fish to hide from predators. Small pelagic planktivorous fish may reduce the risk of predation by schooling, lessening their conspicuousness through camouflage, or by migrating into waters with reduced light intensity (Pitcher 1993, Appenzeller \& Leggett 1995, Warrant \& Locket 2004). Reducing visibility has also been suggested for the vertical migrations of the mesopelagic pearlside Maurolicus muelleri. These migrations probably reduce predation risk from visually foraging predators (Giske et al. 1990, Rosland \& Giske 1997).

Different ontogenetic stages of Maurolicus muelleri form distinct homogenous sound scattering layers 
(SLs) at different depths during day and night time (Giske et al. 1990, Baliño \& Aksnes 1993, Staby 2010). The species inhabits deeper waters during daytime, ascends to the surface at dusk to feed during the crepuscular periods (Bagøien et al. 2001), and descends again to daytime depth as surface light intensity increases at dawn. M. muelleri possibly takes advantage of the 'anti-predation window' during the crepuscular hours, by foraging at a light level with reduced predation risk (Clark \& Levy 1988, Appenzeller \& Leggett 1995, Scheuerell \& Schindler 2003).

Which aspect of changing light intensity governs the migrations of fish? Whether it is the change in absolute light intensity (Widder \& Frank 2001), the relative rate of change in light intensity (Ringelberg 1995, Ringelberg \& Van Gool 2003), a certain light threshold that is required to initiate a behavioural response (Sweatt \& Forward 1985), or other unrevealed mechanisms is not entirely clear (Neilson \& Perry 1990, Johnsen 2005). Several studies of planktonic organisms suggest that the relative rate of change in light intensity is the proximate cause and initiating cue of diel vertical migrations (DVMs; Ringelberg 1995, Cohen \& Forward 2009), although a recent study of the deep water jellyfish Periphylla periphylla (Dupont et al. 2009) suggested that migration at the population level can be ascribed to a preference of a certain light range at the individual level. Studies of planktivores have also suggested that fish follow a preferred light intensity during their migrations (Eggers 1978, Bohl 1980, Appenzeller \& Leggett 1995).

Maurolicus muelleri is known to change its vertical position immediately with changing surface light levels, not only during dusk and dawn, but also during daytime (Giske et al. 1990, Baliño \& Aksnes 1993, Rasmussen \& Giske 1994, Kaartvedt et al. 1998). As has been hypothesised for Periphylla periphylla (Dupont et al. 2009), this behaviour suggests that individuals prefer a certain light range during daytime as well as during dusk and dawn. At the population level, such behaviour might appear as if the individuals (i.e. the population average) follow a preferred light intensity, a so-called isolume. To what extent the vertical distribution of $M$. muelleri can be characterised by such behaviour beyond the daily time scale is unknown.

Here we investigated the relationship between variations in the depth distribution of Maurolicus muelleri and the variations of incoming surface irradiance beyond the daily time scale such as consecutive days with similar and dissimilar sky conditions. We hypothesised that the variations in the depth of the SLs of M. muelleri can be accounted for by proximate isolume behaviour, i.e. that $M$. muelleri relocate vertically to keep the ambient light intensity constant. If the fish behave correspondingly, then the depth of the SLs is expected to be linearly related to the logarithm of the surface irradiance (see 'Materials and methods'). We tested this expectation by analysing continuously recorded surface irradiance and acoustic data from selected days in a 9 mo period (January to September 2008).

\section{MATERIALS AND METHODS}

The study location was Masfjorden $\left(60^{\circ} 50^{\prime} \mathrm{N}\right.$; $5^{\circ} 25^{\prime} \mathrm{E}$ ) on the west coast of Norway (Kaartvedt et al. 1988). Surface irradiance (photosynthetically active radiation, PAR at 400 to $700 \mathrm{~nm}$ ) was collected between January and September 2008 and was measured with a calibrated LI-190 quantum sensor (LI-COR Biosciences) and stored on a LI-1400 data logger (LI-COR Biosciences). Irradiance was sampled every $30 \mathrm{~s}$ and averages logged every $15 \mathrm{~min}$. The sensor was mounted approximately $2 \mathrm{~m}$ above the sea surface with minimal obstruction (shadowing) from surrounding structures. During the same period, acoustic data of the entire water column were recorded with an upward facing EK60 $38 \mathrm{kHz}$ split beam echosounder (SIMRAD) mounted at the bottom $(392 \mathrm{~m})$ and located approximately $1 \mathrm{~km}$ away from the location of the quantum sensor. The echosounder settings were described in detail by Kaartvedt et al. (2009). In Masfjorden, daytime SLs above $200 \mathrm{~m}$ are practically homogenous and dominated (>95\% in terms of number and weight) by Maurolicus muelleri (Kaartvedt et al. 2009, Staby 2010).

SL depth estimation. Data presented in this study are from selected paired (consecutive) days, which either had nearly identical (sunny or overcast) or dissimilar (sunny versus overcast) surface irradiance, as well as clearly distinguishable SLs in the period January to September 2008. SLs in June were generally hazy and diffuse, and it was thus not possible to obtain reliable depth estimates for this month. For all other months, we obtained depth estimates of the upper border of different SLs and estimated the depth of the shallowest SL (SSL) in January to April and the depth of the deep SL (DSL) in May to September. Acoustic data from the upper $250 \mathrm{~m}$ recorded in periods when surface PAR was higher than the threshold sensitivity for the irradiance sensor $\left(0.0001 \mu \mathrm{E} \mathrm{m}^{-2} \mathrm{~s}^{-1}\right)$ was divided into $10 \mathrm{~min}$ (horizontal) and $1 \mathrm{~m}$ (vertical) bins. The average volume backscattering (Sv), i.e. the amount of acoustic energy reflected by $1 \mathrm{~m}^{3}$, was calculated for each bin using the biomass calculation setup in SONAR5-PRO (Balk \& Lindem 2009). The upper boundary of an SL was then defined as the depth where the average $\mathrm{Sv}$ dropped below $-75 \mathrm{~dB}$. The depth estimates were plotted against time and superimposed on daily echograms to assess how well they corresponded with the SLs. 
Data analysis. Although it is likely that fish have a preferred range of light intensities rather than a particular intensity, we simplified the approach and assume a single value in our analysis, a so-called isolume, and report on the variation in this estimate. The hypothesis that fish stay at a depth following an isolume (given as the downwelling irradiance, $E_{\text {iso }}$ ), can be expressed as:

$$
E_{\text {iso }}=E_{0} \mathrm{e}^{-K Z_{\text {iso }}}
$$

where $Z_{\text {iso }}$ is the isolume depth, $E_{0}$ is surface irradiance, and $K$ is the attenuation coefficient for downwelling irradiance. Solving Eq. (1) for $Z_{\text {iso }}$

$$
Z_{\text {iso }}=\frac{1}{K} \ln E_{0}-\frac{1}{K} \ln E_{\text {iso }}
$$

Eq. (2) is of the form $y=a x+b$, where the slope $a$ equals $\frac{1}{K}, x$ equals $\ln E_{0}$, and the intercept $b$ equals $-\frac{1}{K} \ln E_{\text {iso }}$ which, according to the above isolume hypothesis, should be a constant (as long as $K$ can be regarded constant). Thus, the expectation is that changes in the depth of the SL (which is an assumed estimate of $Z_{\text {iso }}$ ) that were obtained from the acoustical observations should be linearly related to the changes in $\ln E_{0}$ that were obtained by the PAR sensor. A linear relationship between SL depth and $\ln E_{0}$ assumes an invariant attenuation coefficient (the rate at which light is reduced as a result of absorption and scattering), and we therefore applied measurements of consecutive days to minimise possible variations in the inherent optical properties of the water column. Since $K$ is an apparent property that is also affected by the angular distribution of light (e.g. affected by the sun elevation and cloudiness), some variations in $K$ are expected. Based on previous observations of $K$ in Masfjorden, it appears fairly stable below 40 to $50 \mathrm{~m}$ in depth (Giske et al. 1990, Baliño \& Aksnes 1993), but the $K$ in Eq. (2) represents the average attenuation between the surface and the actual depth and will therefore be somewhat affected by variations in angular distribution of light, e.g. between a cloudy and sunny day. Despite these uncertainties concerning $K$, we investigated to what extent Eq. (2) could account for the observed variations in the depth of the SLs during entire day periods, as well as for limited periods during the observed dawn descents and dusk ascents. The analyses were limited to periods when $E_{0}$ was $>0.0001 \mu \mathrm{E}$ $\mathrm{m}^{-2} \mathrm{~s}^{-1}$ and the estimated $Z_{\text {iso }}$ was deeper than $40 \mathrm{~m}$.

The hypothesis of a preferred light intensity implies $Z_{\text {iso }}$ to be similar on consecutive days with similar surface irradiance (e.g. 2 sunny days), and different on days with dissimilar surface irradiance (e.g. a sunny versus a cloudy day). The ascent and descent periods around dawn and dusk were defined as follows: fish descended (ascended) as long as the difference of sub- tracted successive depth estimates was positive (negative), while the migration ended when either 0 or negative (positive) values were obtained.

Eq. (2) can be rearranged such that:

$$
\frac{b}{a}=\frac{-\frac{1}{K} \ln E_{\text {iso }}}{\frac{1}{K}}=-\ln E_{\text {iso }}
$$

Thus, the irradiance of the isolume $E_{\text {iso }}$ at depth $Z_{\text {iso }}$ can be estimated according to:

$$
E_{\text {iso }}=\mathrm{e}^{-\frac{b}{a}}
$$

An implicit assumption of Eq. (4) is an invariant $K$ during the period of observation.

Statistical analysis. Similarity of regression slopes was tested by applying an analysis of regression slope homogeneity in STATISTICA 8 (StatSoft). In the homogeneity-of-slopes model, the dependent variable was depth $\left(Z_{\text {iso }}\right)$, the continuous predictor was $\ln E_{0}$, and the categorical independent variable was date (day).

\section{RESULTS}

\section{Consecutive days with similar surface irradiance}

Maximum surface irradiance (1250 to $1500 \mu \mathrm{E} \mathrm{m}^{-2} \mathrm{~s}^{-1}$ ) was 12 to 15 times higher on sunny days in April and May than on overcast days in January $\left(<100 \mu \mathrm{E} \mathrm{m}^{-2} \mathrm{~s}^{-1}\right.$; Fig. 1). Irradiance increased until midday (11:30 to 12:00 h UTC) and decreased in a similar pattern, with few irregular fluctuations in irradiance over the course of a day (Fig. 1). The irradiance increased abruptly at 06:00 h in April, probably because of the sun appearing from behind the surrounding mountains. In April and May, respectively, the irradiance fell abruptly at 16:30 and 17:00 h, likely as a result of the sun disappearing behind mountains surrounding the fjord.

The depth variations of the SLs' upper border reflected the variations in the logarithmic surface irradiance and were 50 to $70 \mathrm{~m}$ deeper at midday in April and May than in January (Fig. 1). Depth estimates of the SL descents and ascents of consecutive days overlapped temporally, while the SL depth difference between consecutive days in May was at times 10 to $20 \mathrm{~m}$.

\section{Consecutive days with dissimilar surface irradiance}

Consecutive days with different surface irradiance in February, March, and July to September are shown in Fig. 2. Two partially overcast days in February had high irradiance variations with between-day differences up to $400 \mu \mathrm{E} \mathrm{m} \mathrm{m}^{-2} \mathrm{~s}^{-1}$. Light levels were approximately 5 times higher on 21 March than on 20 March. 


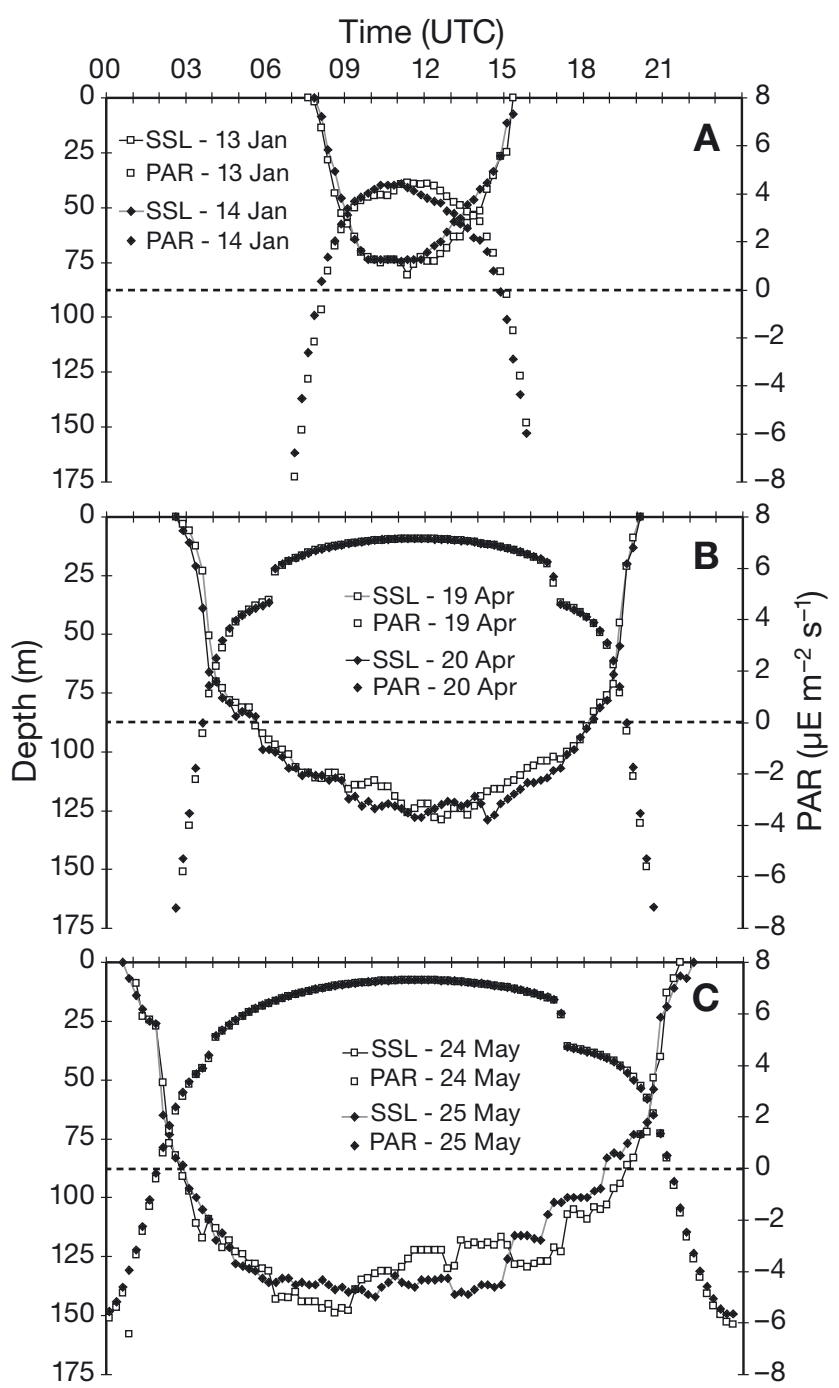

Fig. 1. Estimated depth of the upper edge of the shallow scattering layer (SSL) and corresponding ln-transformed surface irradiance (photosynthetically active radiation, PAR) on days with similar surface light intensity. (A) January, (B) April, (C) May 2008. The dashed horizontal reference line

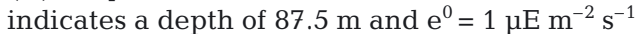

However, on $21 \mathrm{March}$, irradiance did not follow the symmetrical dome-shaped distribution, which is typical for an entirely sunny day. July 10 was an entirely sunny day (1500 $\mu \mathrm{E} \mathrm{m}^{-2} \mathrm{~s}^{-1}$ at midday), compared to the overcast 13 July $\left(620 \mu \mathrm{E} \mathrm{m}^{-2} \mathrm{~s}^{-1}\right.$; Fig. 2); 8 August had some irregular irradiance measurements but was otherwise sunny, while 13 September was an entirely sunny day. Differences between average daily irradiance were 370 and $425 \mu \mathrm{E} \mathrm{m}{ }^{-2} \mathrm{~s}^{-1}$ in August and September, respectively.

With the exception of the DSL in September, SLs were distributed deeper when corresponding surface irradiance measurements were higher (Fig. 2). The average difference in depth of the upper SL edge on consecutive days (calculated as the average depth between the end of the descent and the start of the ascent) was approximately 15, 30, 20 and $20 \mathrm{~m}$ in February, March, July and August, respectively.

\section{Regressions}

The estimated regression equations (see Eq. 2) for SL depth versus log-transformed surface irradiance are summarised in Table 1. Most regressions were significant at $\mathrm{p}<0.001$, with a coefficient of determination $\mathrm{R}^{2}>0.9$, and all were significant at $\mathrm{p}<0.05$. Thus, a strong effect of light on the daytime, dawn, and dusk depth distribution appears for all investigated dates. Slope (a) as well as intercept (b) estimates generally displayed less variation on consecutive days with similar irradiance (January, April and May) than on days with different surface irradiance (Table 1). Analysis of slope homogeneity showed that slope variation was highest on consecutive days with different surface light intensities and most significant in March and September (Table 2). Variations in the slope could have been caused by methodological weaknesses, SLs not strictly following a preferred light intensity or by variations in $K$ due to variations in the angular distribution of light between e.g. cloudy and sunny days. According to Eq. (2), the slope is the reciprocal of $K$, and the observed slope variations in March and September correspond to variations in $K\left(\mathrm{~m}^{-1}\right)$ in the range of 0.054 to 0.073 and 0.047 to 0.071 , respectively. Alternatively, the slope variations for these 2 months might reflect a variation in preferred irradiance in the range

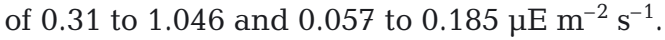

Slopes of the descent and ascent periods from consecutive days were generally similar, with the exception of descents in February and May, and ascents in April and May (Table 2).

\section{Estimated light levels at SL depth}

According to Eq. (2), the light preference values or isolumes $\left(E_{\text {iso }}\right)$ can be estimated from the estimated slopes and the intercepts of the regression equations in Table 1, i.e. $E_{\text {iso }}=\mathrm{e}^{-b / a}$. As noted above, such estimates of $E_{\text {iso }}$ will also be affected by potential variations in $K$ within the time period for which the regression coefficients are estimated.

Estimated isolumes $\left(E_{\text {iso }}\right)$, based on entire days as well as descent and ascent migrations, were similar on consecutive days, but varied between months (Fig. 3). On consecutive days, estimates of $E_{\text {iso }}$ differed by an average factor of 3 during daylight periods, while $E_{\text {iso }}$ 

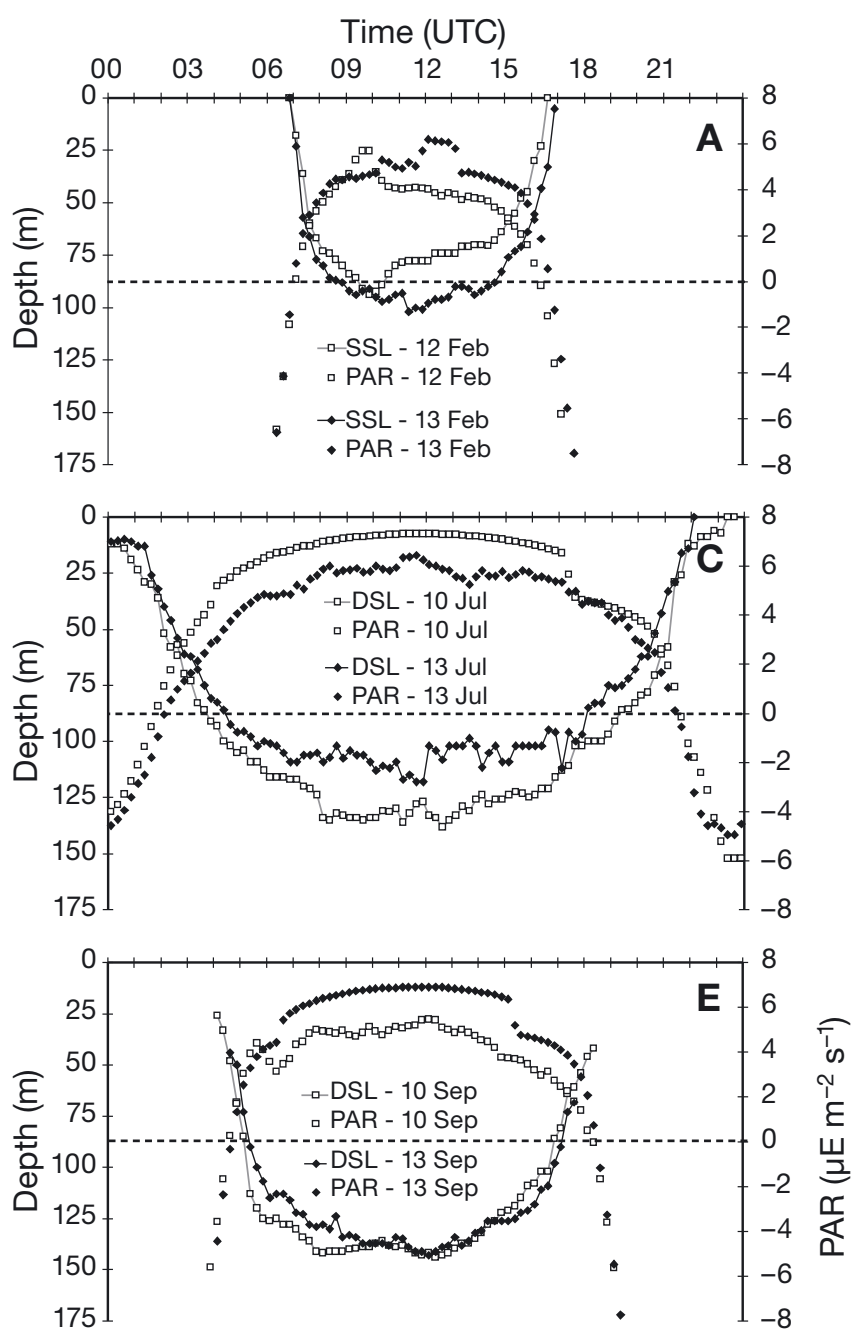
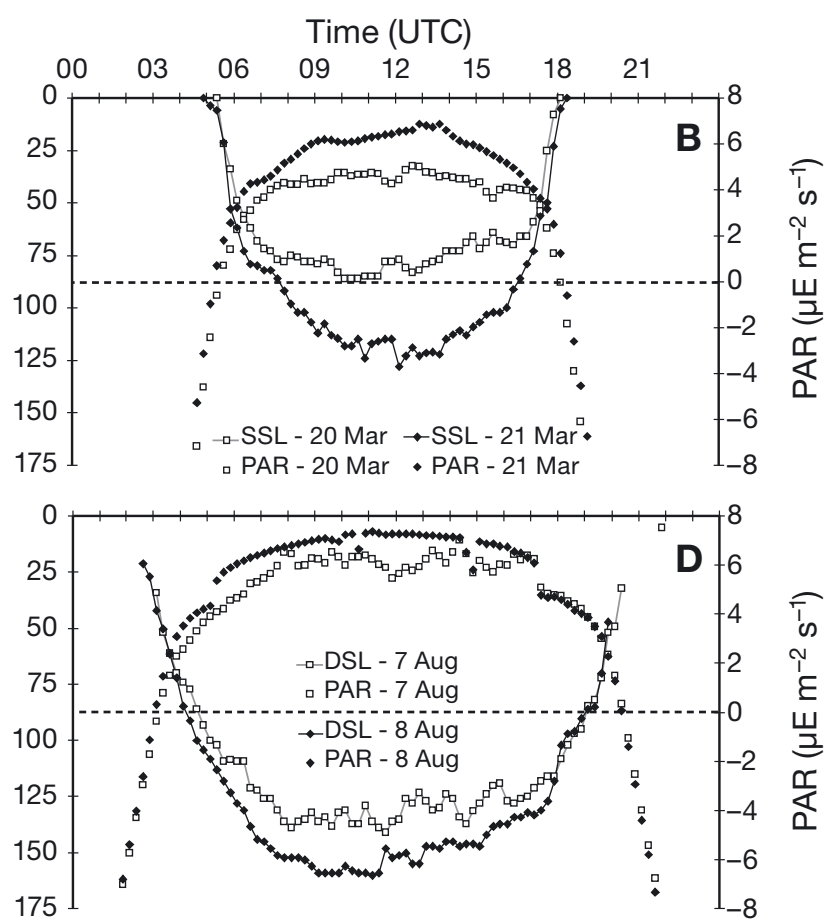

Fig. 2. Estimated depth of the upper border of shallow (SSL) and deep scattering layers (DSL), with corresponding lntransformed surface irradiance (photosynthetically active radiation, PAR) on days with dissimilar surface light intensity. (A) February, (B) March, (C) July, (D) August, (E) September 2008. The dashed horizontal reference line indicates a depth

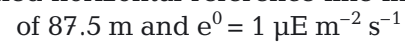

Table 1. Summary of linear regressions (Eq. 2) with data from the entire day and from descent and ascent periods (defined in 'Materials and methods'). The regression slope $(a)$ and the regression intercept $(b)$ were used to estimate the irradiance of the iso-

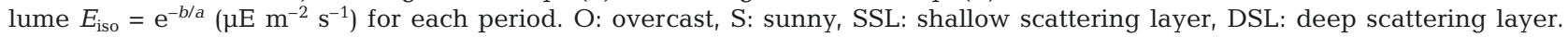
Regression significance levels: ${ }^{* *} \mathrm{p}<0.01 ;{ }^{* * *} \mathrm{p}<0.001$

\begin{tabular}{|c|c|c|c|c|c|c|c|c|c|c|c|c|c|c|c|}
\hline \multirow[t]{2}{*}{ Month } & \multirow[t]{2}{*}{ Days } & \multirow{2}{*}{$\begin{array}{l}\text { Wea- } \\
\text { ther }\end{array}$} & \multirow{2}{*}{$\begin{array}{l}\text { Scatter- } \\
\text { ing layer }\end{array}$} & \multicolumn{4}{|c|}{ — Entire day period — } & \multicolumn{4}{|c|}{ - Descent period } & \multicolumn{4}{|c|}{ Ascent period } \\
\hline & & & & $a$ & $b$ & $\mathrm{R}^{2}$ & $E_{\text {iso }}$ & $a$ & $b$ & $\mathrm{R}^{2}$ & $E_{\text {iso }}$ & $a$ & $b$ & $\mathrm{R}^{2}$ & $E_{\text {iso }}$ \\
\hline January & $\begin{array}{l}13 \\
14\end{array}$ & $\begin{array}{l}\mathrm{O} \\
\mathrm{O}\end{array}$ & $\begin{array}{l}\text { SSL } \\
\text { SSL }\end{array}$ & $\begin{array}{l}14.3 \\
14.7\end{array}$ & $\begin{array}{l}13.8 \\
11.3\end{array}$ & $\begin{array}{l}0.93^{* * *} \\
0.94^{* * *}\end{array}$ & $\begin{array}{l}0.38 \\
0.46\end{array}$ & $\begin{array}{l}14.7 \\
15.4\end{array}$ & $\begin{array}{l}15.4 \\
12.7\end{array}$ & $\begin{array}{c}0.98^{* * *} \\
0.99^{* *}\end{array}$ & $\begin{array}{l}0.35 \\
0.44\end{array}$ & $\begin{array}{l}16.1 \\
16.6\end{array}$ & $\begin{array}{l}5.5 \\
3.5\end{array}$ & $\begin{array}{c}0.97^{* *} \\
0.98^{* * *}\end{array}$ & $\begin{array}{l}0.71 \\
0.81\end{array}$ \\
\hline February & $\begin{array}{l}12 \\
13\end{array}$ & $\begin{array}{l}\mathrm{O} \\
\mathrm{O}\end{array}$ & $\begin{array}{l}\text { SSL } \\
\text { SSL }\end{array}$ & $\begin{array}{l}12.1 \\
12.1\end{array}$ & $\begin{array}{l}28 \\
31\end{array}$ & $\begin{array}{l}0.93^{* * *} \\
0.81^{* * *}\end{array}$ & $\begin{array}{l}0.10 \\
0.08\end{array}$ & $\begin{array}{c}9.5 \\
14.1\end{array}$ & $\begin{array}{c}38.2 \\
27\end{array}$ & $\begin{array}{l}0.98^{* * *} \\
0.97^{* * *}\end{array}$ & $\begin{array}{l}0.02 \\
0.15\end{array}$ & $\begin{array}{l}14.3 \\
17.6\end{array}$ & $\begin{array}{c}20.7 \\
7.1\end{array}$ & $\begin{array}{l}0.98^{* * *} \\
0.94^{* * *}\end{array}$ & $\begin{array}{l}0.24 \\
0.67\end{array}$ \\
\hline March & $\begin{array}{l}20 \\
21\end{array}$ & $\stackrel{\mathrm{O}}{\mathrm{S}}$ & $\begin{array}{l}\text { SSL } \\
\text { SSL }\end{array}$ & $\begin{array}{l}13.7 \\
18.4\end{array}$ & $\begin{array}{l}16.05 \\
-0.83\end{array}$ & $\begin{array}{l}0.79^{* * *} \\
0.96^{* * *}\end{array}$ & $\begin{array}{l}0.31 \\
1.05\end{array}$ & $\begin{array}{l}14.1 \\
15.5\end{array}$ & $\begin{array}{l}17.9 \\
12.8\end{array}$ & $\begin{array}{c}0.99^{* * *} \\
1^{* * *}\end{array}$ & $\begin{array}{l}0.28 \\
0.44\end{array}$ & $\begin{array}{c}18 \\
24.9\end{array}$ & $\begin{array}{c}-5 \\
-30.3\end{array}$ & $\begin{array}{c}0.97^{* *} \\
0.98^{* * *}\end{array}$ & $\begin{array}{l}1.3 \\
3.4\end{array}$ \\
\hline April & $\begin{array}{l}19 \\
20\end{array}$ & $\begin{array}{l}\mathrm{S} \\
\mathrm{S}\end{array}$ & $\begin{array}{l}\text { SSL } \\
\text { SSL }\end{array}$ & $\begin{array}{c}10.9 \\
11\end{array}$ & $\begin{array}{c}40.9 \\
43\end{array}$ & $\begin{array}{l}0.92^{* * *} \\
0.93^{* * *}\end{array}$ & $\begin{array}{l}0.02 \\
0.02\end{array}$ & $\begin{array}{l}9.2 \\
7.2\end{array}$ & $\begin{array}{l}44.6 \\
54.2\end{array}$ & $\begin{array}{l}0.91^{* *} \\
0.94^{* *}\end{array}$ & $\begin{array}{c}0.01 \\
0.001\end{array}$ & $\begin{array}{l}14.9 \\
11.6\end{array}$ & $\begin{array}{l}30.4 \\
42.6\end{array}$ & $\begin{array}{l}0.96^{* * *} \\
0.93^{* * *}\end{array}$ & $\begin{array}{l}0.13 \\
0.03\end{array}$ \\
\hline May & $\begin{array}{l}24 \\
25\end{array}$ & $\begin{array}{l}\mathrm{S} \\
\mathrm{S}\end{array}$ & $\begin{array}{l}\text { DSL } \\
\text { DSL }\end{array}$ & $\begin{array}{c}11.6 \\
13\end{array}$ & $\begin{array}{l}50.2 \\
41.8\end{array}$ & $\begin{array}{l}0.78^{* * *} \\
0.86^{* * *}\end{array}$ & $\begin{array}{l}0.01 \\
0.04\end{array}$ & $\begin{array}{l}18.2 \\
12.7\end{array}$ & $\begin{array}{c}43 \\
52.8\end{array}$ & $\begin{array}{l}0.96^{* * *} \\
0.99^{* * *}\end{array}$ & $\begin{array}{l}0.09 \\
0.02\end{array}$ & $\begin{array}{l}21.4 \\
13.5\end{array}$ & $\begin{array}{c}8.2 \\
28.6\end{array}$ & $\begin{array}{c}0.98^{* * *} \\
0.94^{* *}\end{array}$ & $\begin{array}{l}0.68 \\
0.12\end{array}$ \\
\hline July & $\begin{array}{l}10 \\
13\end{array}$ & $\begin{array}{l}\mathrm{S} \\
\mathrm{O}\end{array}$ & $\begin{array}{l}\text { DSL } \\
\text { DSL }\end{array}$ & $\begin{array}{l}13.7 \\
11.9\end{array}$ & $\begin{array}{l}30.7 \\
38.2\end{array}$ & $\begin{array}{l}0.96^{* * *} \\
0.88^{* * *}\end{array}$ & $\begin{array}{l}0.11 \\
0.04\end{array}$ & $\begin{array}{l}11.8 \\
13.8\end{array}$ & $\begin{array}{l}36.1 \\
40.2\end{array}$ & $\begin{array}{l}0.98^{* * *} \\
0.99^{* * *}\end{array}$ & $\begin{array}{l}0.05 \\
0.05\end{array}$ & $\begin{array}{l}16.4 \\
15.2\end{array}$ & $\begin{array}{l}20.7 \\
18.4\end{array}$ & $\begin{array}{l}0.93^{* * *} \\
0.95^{* * *}\end{array}$ & $\begin{array}{l}0.28 \\
0.30\end{array}$ \\
\hline August & $\begin{array}{l}7 \\
8\end{array}$ & $\begin{array}{l}\mathrm{O} \\
\mathrm{S}\end{array}$ & $\begin{array}{l}\text { DSL } \\
\text { DSL }\end{array}$ & $\begin{array}{c}16 \\
18.3\end{array}$ & $\begin{array}{c}32.2 \\
22\end{array}$ & $\begin{array}{l}0.92^{* * *} \\
0.94^{* * *}\end{array}$ & $\begin{array}{l}0.13 \\
0.30\end{array}$ & $\begin{array}{l}16.1 \\
17.9\end{array}$ & $\begin{array}{l}35.3 \\
24.6\end{array}$ & $\begin{array}{l}0.96^{* * *} \\
0.97^{* * *}\end{array}$ & $\begin{array}{l}0.11 \\
0.25\end{array}$ & $\begin{array}{c}20 \\
25.2\end{array}$ & $\begin{array}{c}12 \\
-7.1\end{array}$ & $\begin{array}{l}0.95^{* * *} \\
0.87^{* * *}\end{array}$ & $\begin{array}{c}0.55 \\
1.3\end{array}$ \\
\hline September & $\begin{array}{l}10 \\
13\end{array}$ & $\stackrel{\mathrm{O}}{\mathrm{S}}$ & $\begin{array}{l}\text { DSL } \\
\text { DSL }\end{array}$ & $\begin{array}{l}21.1 \\
14.1\end{array}$ & $\begin{array}{l}35.6 \\
40.4\end{array}$ & $\begin{array}{l}0.92^{* * *} \\
0.87^{* * *}\end{array}$ & $\begin{array}{l}0.19 \\
0.06\end{array}$ & $\begin{array}{l}19.7 \\
21.2\end{array}$ & $\begin{array}{l}38.9 \\
20.7\end{array}$ & $\begin{array}{c}0.90^{* *} \\
1^{* * *}\end{array}$ & $\begin{array}{l}0.14 \\
0.38\end{array}$ & $\begin{array}{l}20.7 \\
22.3\end{array}$ & $\begin{array}{l}28.3 \\
3.4\end{array}$ & $\begin{array}{l}0.88^{* *} \\
0.67^{* *}\end{array}$ & $\begin{array}{l}0.26 \\
0.86\end{array}$ \\
\hline
\end{tabular}


Table 2. Summary of slope homogeneity analysis based on data from entire day periods, as well as descent and ascent periods. Numbers are significance levels $\left({ }^{*} p<0.05 ;{ }^{* *} p<0.01 ;{ }^{* * *} p<0.001\right)$ and give an indication of similarity of regression slopes from consecutive days, such that non-significant numbers imply similar (parallel) slopes. (O: overcast, S: sunny; DSL: deep scattering layer, SSL: shallow scattering layer)

\begin{tabular}{|lcccccc|}
\hline Month & Days & Weather & $\begin{array}{c}\text { Scattering } \\
\text { layer }\end{array}$ & $\begin{array}{c}\text { Entire } \\
\text { day period }\end{array}$ & $\begin{array}{c}\text { Descent } \\
\text { period }\end{array}$ & $\begin{array}{c}\text { Ascent } \\
\text { period }\end{array}$ \\
\hline January & 13 and14 & O & SSL & 0.731 & 0.576 & 0.778 \\
February & 12 and 13 & O & SSL & 0.993 & $0.001^{* * *}$ & 0.186 \\
March & 20 and 21 & O and S & SSL & $0.001^{* * *}$ & 0.136 & 0.054 \\
April & 19 and 20 & S & SSL & 0.818 & 0.342 & $0.044^{*}$ \\
May & 24 and 25 & S & SSL & 0.149 & $0.004^{* *}$ & $0.006^{* *}$ \\
July & 10 and13 & O and S & DSL & $0.004^{* *}$ & $0.02^{* *}$ & 0.588 \\
August & 7 and 8 & O and S & DSL & $0.006^{* *}$ & 0.327 & 0.15 \\
September & 10 and 13 & O and S & DSL & $0.001^{* * *}$ & 0.715 & 0.812 \\
\hline
\end{tabular}

from descents and ascents differed by an average factor of 5 and 3 , respectively. On 13 out of 16 days, $E_{\text {iso }}$ was between 2 and 9 times higher during the ascent than the descent phase. Seasonal variation of $E_{\text {iso }}$ was generally highest in the first 5 mo (January to May), while the isolume intensity at the DSL depth seemed to be similar in July to September (Fig. 3).

\section{Surface light at dusk and dawn}

Light intensities at the surface before Maurolicus muelleri descended from the surface at dawn and arrived at

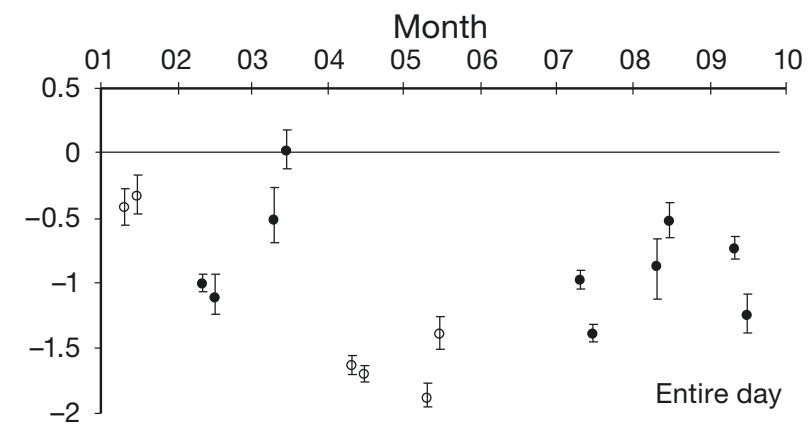
dusk after ascent were compared with corresponding $E_{\text {iso }}$ estimates from the descent and ascent phases (Fig. 3). In the period January to May, estimates of the preferred irradiance during descents and ascents often overlapped with the surface light recordings (Fig. 3). In July to September, the DSL could not be tracked all the way to the surface (see also Fig. 2), and it was therefore not possible to obtain a time of surface arrival with a corresponding surface light recording.

\section{DISCUSSION}

The linear relationships we report between SL depth and the logarithmic surface irradiance indicate that changes in the vertical distribution of the SLs are greatly affected by changes in light. However, our study does not suggest that the 2 Maurolicus muelleri SLs are strictly attracted to invariant universal light intensities as suggested by the isolume concept; rather, the phrase 'a preferred range of light intensities' seems more appropriate. The similarity between the actual measured surface light when $M$. muelleri were at the surface and the indirect estimates of the preferred irradiance that were obtained by Eq. (4) in the period January to May (Fig. 3) suggest that the indirect estimates of the light preference appear reasonable.

Our results suggest that the ambient light level at Maurolicus muelleri SL depth is similar on consecutive days, when variation in $K$ is likely to be small and similar. On successive days with different surface irradiance, M. muelleri SLs were consistently distributed shallower on overcast days (with the exception of September), indicating that SLs adjusted their depth to a similar preferred light intensity on the 2 days with different surface irradiance. These observations add to the within-day observations of Baliño \& Aksnes (1993), who observed that SLs rapidly adjusted their depths
Fig. 3. Estimated irradiance ( $\log _{10}$ transformed) of the isolume $E_{\text {iso }}$ at the upper border of scattering layers (SLs). Solid circles are consecutive days with dissimilar surface light intensity, while open circles indicate consecutive days with similar light intensity. Error bars show 95\% confidence intervals of the estimated light level. Crosses indicate measured surface light intensities when Maurolicus muelleri were observed at the surface at dawn (before descent) and dusk (after ascent). Horizontal line corresponds to $1 \mu \mathrm{E} \mathrm{m}^{-2} \mathrm{~s}^{-1}$ 
upward when surface light intensity dropped as a result of sudden cloudiness. Thus, these observations suggest a preference for an absolute light intensity both within and between days.

We assumed an invariant light attenuation coefficient $K$ when estimating preferred light intensities. However, $K$ can vary as a result of variations in the light field above and below the air-water interface. Several studies have indicated that mesopelagic organisms moved to shallower areas with increased turbidity, i.e. increases in $K$ (Kaartvedt et al. 1996, Widder \& Frank 2001, Frank \& Widder 2002). Solar elevation (solar zenith angle) and sky conditions, however, also affect the angular distribution of light and thereby $K$ (Zheng et al. 2002), and changes in solar elevation may affect $K$ with $25 \%$ variation (Jerlov 1968). Additionally, in contrast to sunny days, irradiance on overcast days is more diffuse than direct, which can result in altered $K$ (Kirk 1984, Zheng et al. 2002). Our results indicate that this might have been the case, as our $K$ estimates were higher on overcast days compared to the sunnier days on 3 out of 4 occasions. Thus $K$ variations might explain some of the observed variation in our $a$ and $b$ estimates (Eq. 2) as well as the estimates of the preferred irradiance (Eq. 4). In future studies, actual measurements of underwater irradiance should be conducted to eliminate this source of variation.

The consistently lower preferred light level of the descent SL compared to the ascent SL suggests that Maurolicus muelleri might respond differently to light during dawn and dusk. Bjelland (1995) and Rasmussen \& Giske (1994) reported that light levels $M$. muelleri SLs experienced at the surface were 2 to 4 orders of magnitude higher at dusk than at dawn, while our study suggests a corresponding 1 order of magnitude difference. After feeding at the surface at dawn, fish are likely to be more satiated on their descent (Bagøien et al. 2001). While ascending at dusk, after a prolonged daytime period with lower foraging rates, fish might take greater risks to feed at higher light intensities (Appenzeller \& Leggett 1995). Alternatively, it may be hypothesised that the diurnal migration pattern of $M$. muelleri is controlled by internal clocks (endogenous or circadian rhythms) adjusted to diurnal and seasonal variations (Neilson \& Perry 1990), rather than by the instantaneous variations in light per se. However, such circadian rhythms cannot account for SLs responding to unpredictable light fluctuations caused by sudden cloud shadows (Baliño \& Aksnes 1993) or changes in water transparency (Frank \& Widder 2002). According to McFarland (1986), the sudden darkening of the sun by cloud cover can reduce the light intensity by as much as $75 \%$ within seconds.

The spectral distribution of downwelling irradiance becomes truncated with increasing depth (Herring
2002), with wavelengths between 450 and 500 nm generally penetrating deepest (McFarland 1986, Warrant $\&$ Locket 2004). Measurements of the spectral distribution in the upper $70 \mathrm{~m}$ in Masfjorden in October 2008 showed that downwelling light peaked between 480 and $510 \mathrm{~nm}$ at $70 \mathrm{~m}$ (A. Staby unpubl. data). The visual pigments of most mesopelagic and deep-sea fish have their highest absorption wavelength between 468 and $494 \mathrm{~nm}$ (Douglas et al. 1998). It is probable that Maurolicus muelleri also orientate according to changes in this spectral range, and that vertical changes of the attenuation coefficient for such a spectral range (Widder \& Frank 2001) will influence the vertical relocating speed when following an isolume.

Recent studies of mesopelagic crustaceans (Onsrud \& Kaartvedt 1998, Widder \& Frank 2001, Frank \& Widder 2002) not only suggested that these organisms followed an upper isolume during their ascents, but also that their swimming speeds were sufficiently high to keep track with the changing isolume depth (Widder \& Frank 2001). Migrating Maurolicus muelleri individuals can achieve vertical swimming speeds of 10 to $20 \mathrm{~cm} \mathrm{~s}^{-1}$ during both descents and ascents (Torgersen \& Kaartvedt 2001), which is probably sufficiently fast to follow the speed of the vertically changing preferred light intensity during crepuscular periods.

We have estimated the irradiance at the top edge of SLs, but an SL extends over a depth range and consequently over a range of light intensities. Acoustic data suggest that individuals or groups of fish may vary their depth within an SL, at times migrating between SLs and thereby experiencing varying ambient light levels (A. Staby unpubl. data). It was difficult to estimate the depth of the lower SL border during the first 5 mo because either SLs were not clearly separated from each other or the lower edge was not clearly defined. However, in July to September, depth estimates from the lower DSL border could be obtained on some days, and the calculated light levels suggest that the light intensity between the upper and lower edge of an SL (20 to $80 \mathrm{~m}$ ) may vary by several orders of magnitude $\left(10^{-1}\right.$ to $\left.10^{-7}\right)$, depending on the vertical extent of the SL. The large difference in irradiance between the upper and lower SL edge suggests a much higher variation in the ambient light for individuals within an SL at a particular time than the temporal variation in the ambient light at the top edge of the SLs. These observations also suggest that Maurolicus muelleri has a larger tolerance for moving into darker water than for moving into too illuminated water. This is reasonable if increased light means higher predation risk and decreased light only means reduced intake of prey as a result of of reduced visibility (Rosland \& Giske 1997). While food intake can be adjusted, predation cannot. 


\section{Ontogeny and variation of preferred light range}

Maurolicus muelleri typically form vertically separate SLs according to their developmental stage, i.e. post-larvae, juveniles and adults (Goodson et al. 1995, Staby 2010). Based on findings by Goodson et al. (1995), we believe that the SSL in the period January to May was composed of varying sized fish, although this cannot be said with certainty (due to the lack of catch data in the present study). In contrast, the DSL in July to September probably contained similarly sized adult $M$. muelleri, based on findings that the lower SL is composed of adult fish $>30 \mathrm{~mm}$, regardless of season (Goodson et al. 1995). While a preferred range of light intensities probably involves ontogenetic variations, as evidenced by the different location of SLs, similar estimates of preferred light intensity for the DSL in July, August and September suggest that ontogenetically alike fish may follow a similar preferred range of light intensities over time. Typically, the ontogenetic stages can be characterised by their degree of transparency and lateral silvering, as well as number of ventral photophores. Post-larvae are transparent with little silvering and few photophores (Robertson 1976), while the more silvery juveniles are less transparent and have more photophores. Adults are entirely silver on their sides and have batteries of ventral photophores. The efficiency with which transparency and silvering make various ontogenetic stages less conspicuous will depend on the light intensity and scattering properties of the water, i.e. depth (Johnsen \& Sosik 2003). Additionally, counterillumination, or the downwelling light produced by photophores, aids in breaking up the silhouette of organisms against a brighter background (Widder 1999). The structure of M. muelleri's ventral photophores is similar to that of the related hatchet fish $\mathrm{Ar}$ gyropelecus hemigymnus (Cavallaro et al. 2004), which produces light with an angular distribution similar to that of downwelling light (Denton et al. 1972). Kaartvedt et al. (2008) suggested that ascending $M$. muelleri minimise a reduction of optimal counter-illumination by having a stepwise saltatory swimming behaviour, with short vertical displacements and prolonged horizontal periods. However, the intensity of counter-illumination will most likely differ with ontogeny due to different numbers of photophores, which may influence the light range followed by post-larvae, juveniles and adults.

In summary, our study suggests that the vertical migration of Maurolicus muelleri appears to emerge as a result of a vertical habitat selection that can be characterised by a preferred range of light intensities, and that these intensities might be state and age dependent.
Acknowledgements. We thank A. Fernö, A. Gro Vea Salvanes, and J.E. Skjæraasen for comments on earlier versions of the manuscript, as well as H. Balk for helping with the analysis of acoustic data.

\section{LITERATURE CITED}

Aksnes DL, Utne ACW (1997) A revised model of visual range in fish. Sarsia 82:137-147

Appenzeller DR, Leggett WC (1995) An evaluation of light mediated vertical migration of fish based on hydroacoustic analysis of the diel vertical movements of rainbow smelt Osmerus mordax. Can J Fish Aquat Sci 52:504-511

Bagøien E, Kaartvedt S, Aksnes DL, Eiane K (2001) Vertical distribution and mortality of overwintering Calanus. Limnol Oceanogr 46:1494-1510

> Baliño B, Aksnes DL (1993) Winter distribution and migration of the sound scattering layers, zooplankton and micronekton in Masfjorden, western Norway. Mar Ecol Prog Ser 102:35-50

Balk H, Lindem T (2009) Sonar4 and Sonar5-Pro post processing systems. Lindem Data Acquisition, Oslo

Bjelland O (1995) Life history tactics of two fjordic populations of Maurolicus muelleri. Cand. scient. thesis, University of Bergen

> Bohl E (1980) Diel pattern of pelagic distribution and feeding in planktivorous fish. Oecologia 44:368-375

> Boscarino BT, Rudstam LG, Loew ER, Millis EL (2009) Predicting the vertical distribution of the opossum shrimp, Mysis relicta, in Lake Ontario: a test of laboratory-based light preferences. Can J Fish Aquat Sci 66:101-113

Boscarino BT, Rudstam LG, Tirabassi J, Janssen J, Loew ER (2010) Light effects on alewife-mysid interactions in Lake Ontario: a combined sensory physiology, behavioural, and spatial approach. Limnol Oceanogr 55:2061-2072

Cavallaro M, Mammola CL, Verdiglione R (2004) Structural and ultrastructural comparison of photophores of two species of deep-sea fishes: Argyropelecus hemigymnus and Maurolicus muelleri. J Fish Biol 64:1552-1567

Clark CW, Levy DA (1988) Diel vertical migration by juvenile sockeye salmon and the antipredation window. Am Nat 131:271-290

Cohen JH, Forward RB (2009) Zooplankton diel vertical migration - a review of proximate control. Oceanogr Mar Biol Annu Rev 47:77-110

$>$ De Robertis A (2002) Size-dependent visual predation risk and the timing of vertical migration: an optimization model. Limnol Oceanogr 47:925-933

$>$ Denton EJ, Gilpin-Brown JB, Wright Source PG (1972) The angular distribution of the light produced by some mesopelagic fish in relation to their camouflage. Proc R Soc Lond B Biol Sci 182:145-158

> Douglas RH, Partridge JC, Marshall NJ (1998) The eyes of deep-sea fish I: lens pigmentation, tapeta and visual pigments. Prog Retin Eye Res 17:597-636

Dupont N, Klevjer TA, Kaartvedt S, Aksnes DL (2009) Diel vertical migration of the deep-water jellyfish Periphylla periphylla simulated as individual responses to absolute light intensity. Limnol Oceanogr 54:1765-1775

> Eggers DM (1978) Limnetic feeding behavior of juvenile sockeye salmon in lake Washington and predator avoidance. Limnol Oceanogr 23:1114-1125

$>$ Frank TM, Widder EA (2002) Effects of a decrease in downwelling irradiance on the daytime vertical distribution patterns of zooplankton and micronekton. Mar Biol 140: $1181-1193$ 
Giske J, Aksnes DL, Baliño B, Kaartvedt S and others (1990) Vertical distribution and trophical interactions of zooplankton and fish in Masfjorden, Norway. Sarsia 75: 65-81

Goodson MS, Giske J, Rosland R (1995) Growth and ovarian development of Maurolicus muelleri during spring. Mar Biol 124:185-195

Herring P (2002) The biology of the deep ocean. Oxford University Press, Oxford

Jerlov NG (1968) Optical oceanography. Elsevier Publishers, New York, NY

Johnsen S (2005) Visual ecology in the high seas. Mar Ecol Prog Ser 287:281-285

> Johnsen S, Sosik HM (2003) Cryptic colouration and mirrored sides as camouflage strategies in near-surface pelagic habitats: implications for foraging and predator avoidance. Limnol Oceanogr 48:1277-1288

Kaartvedt S, Aksnes DL, Aadnesen A (1988) Winter distribution of macroplankton and micronekton in Masfjorden, western Norway. Mar Ecol Prog Ser 45:45-55

Kaartvedt S, Melle W, Knutsen T, Skjoldal HR (1996) Vertical distribution of fish and krill beneath water of varying optical properties. Mar Ecol Prog Ser 136:51-58

Kaartvedt S, Knutsen T, Holst JC (1998) Schooling of the vertically migrating mesopelagic fish Maurolicus muelleri in light summer nights. Mar Ecol Prog Ser 170:287-290

Kaartvedt S, Torgersen T, Klevjer TA, Røstad A, Devine JA (2008) Behaviour of individual mesopelagic fish in acoustic scattering layers of Norwegian fjords. Mar Ecol Prog Ser 360:201-209

Kaartvedt S, Røstad A, Klevjer TA, Staby A (2009) Use of bottom-mounted echo sounders in exploring behavior of mesopelagic fishes. Mar Ecol Prog Ser 395:109-118

Kirk JTO (1984) Dependence of relationship between inherent and apparent optical properties of water on solar altitude. Limnol Oceanogr 29:350-356

McFarland WN (1986) Light in the sea-correlations with behaviour of fishes and invertebrates. Am Zool 26: 389-401

Metcalfe JD, Righton D, Eastwood P, Hunter E (2008) Migration and habitat choice in marine fishes. In: Magnhagen $C$, Braithwaite VA, Forsgren E, Kapoor BG (eds) Fish behaviour. Science Publishers, Enfield, NH, p 187-234

Neilson JD, Perry RI (1990) Diel vertical migrations of marine fishes: an obligate or facultative process? Adv Mar Biol 26: 115-168

Onsrud MSR, Kaartvedt S (1998) Die1 vertical migration of the krill Meganyctiphanes norvegica in relation to physical environment, food and predators. Mar Ecol Prog Ser 171:209-219

Editorial responsibility: Hans Heinrich Janssen, Oldendorf/Luhe, Germany
Pitcher TJ (1993) Functions of shoaling behaviour in teleosts. In: Pitcher TJ (ed) Behaviour of teleost fishes. Chapman and Hall, London

> Rasmussen OI, Giske J (1994) Life history parameters and vertical distribution of Maurolicus muelleri in Masfjorden in summer. Mar Biol 120:649-664

> Ringelberg J (1995) Changes in light-intensity and diel vertical migration - a comparison of marine and freshwater environments. J Mar Biol Assoc UK 75:15-25

Ringelberg J, Van Gool E (2003) On the combined analysis of proximate and ultimate aspects in diel vertical migration (DVM) research. Hydrobiologia 491:85-90

Robertson DA (1976) Planktonic stages of Maurolicus muelleri (Teleostei: Sternoptychidae) in New Zealand waters. NZ J Mar Freshw Res 10:311-328

> Roe HSJ (1983) Vertical distributions of euphausiids and fish in relation to light intensity in the northeastern Atlantic. Mar Biol 77:287-298

Rosland R, Giske J (1997) A dynamic model for the life history of Maurolicus muelleri, a pelagic planktivorous fish. Fish Oceanogr 6:19-34

Ryer CH, Olla BL (1998) Effect of light on juvenile walleye pollock shoaling and their interaction with predators. Mar Ecol Prog Ser 167:215-226

Ryer CH, Olla BL (1999) Light-induced changes in the prey consumption and behaviour of two juvenile planktivorous fish. Mar Ecol Prog Ser 181:41-51

Scheuerell MD, Schindler DE (2003) Diel vertical migration by juvenile sockeye salmon: empirical evidence for the antipredation window. Ecology 84:1713-1720

Staby A (2010) Seasonal dynamics in the vertical migration behaviour of mesopelagic fish. PhD dissertation, University of Bergen

Sweatt AJ, Forward RB (1985) Diel vertical migration and photoresponses of the chaetognath Sagitta hispida Conant. Biol Bull (Woods Hole) 168:18-31

Torgersen T, Kaartvedt S (2001) In situ swimming behaviour of individual mesopelagic fish studied by split-beam echo target tracking. ICES J Mar Sci 58:346-354

Warrant EJ, Locket NA (2004) Vision in the deep. Biol Rev Camb Philos Soc 79:671-712

Widder EA (1999) Bioluminescence. In: Archer SN, Djamgoz MBA, Loew ER, Partridge JC (eds) Adaptive mechanisms in the ecology of vision. Kluwer Academic Publishers, Dordrecht

- Widder EA, Frank TM (2001) The speed of an isolume: a shrimp's eye view. Mar Biol 138:669-677

- Zheng X, Dickey T, Chang G (2002) Variability of the downwelling diffuse attenuation coefficient with consideration of inelastic scattering. Appl Opt 41:6477-6488

Submitted: September 3, 2010; Accepted: November 15, 2010 Proofs received from author(s): January 25, 2010 